\title{
Patient's perception on glaucoma and different types of treatment (medical versus surgical treatment)
}

\section{Percepção dos pacientes portadores de glaucoma sobre sua doença e os diferentes tipos de tratamento (clínico versus cirúrgico)}

Augusto Alves Pinho Vieira' ${ }^{1}$, Ricardo Augusto Paletta Guedes², Rita de Cássia Padula Alves Vieira ${ }^{3}$, Vanessa Maria Paletta Guedes ${ }^{4}$

\begin{abstract}
Objective: To identify the meaning and impact on their quality of life of having glaucoma and to understand the patients' perception on the different types of treatment (medical or surgical). Methods: Through a qualitative research, focus groups were conducted with patients in clinical treatment (group 1) and patients who underwent glaucoma surgery in both eyes and were without medication (group 2). The responses were analyzed using the technique of content analysis. Results: Fear of blindness and lack of information about the disease were the most cited issues in relation to how it is like to having glaucoma. Medication costs, impact of drops on patients' daily lives and the side effects were the main points discussed in relation to medical treatment. All patients in the surgical group preferred the current situation (without medication) when compared to the need for chronic use of medication. In the two groups, both glaucoma and its treatment had a profound impact on people, not only from a psychological standpoint, but also affecting their daily lives. Patients operated on for glaucoma appear to have less impact on their daily lives, but the concern about the disease persists. Conclusion: We identified the most significant negative aspects of glaucoma and its treatment from patients' perspectives. Confidence in the correct indication of the type of treatment, clinical or surgical, and a solid relationship between the patient the doctor are determining factors for extra peace of mind of patients being treated for glaucoma.
\end{abstract}

Keywords: Glaucoma, open-angle/psychology; Glaucoma, open-angle/therapy; Glaucoma, open-angle/surgery; Quality of life

\section{RESUMO}

Objetivo: Identificar a percepção dos pacientes sobre o significado de ser portador de glaucoma e a percepção que tem sobre o tratamento clínico ou cirúrgico. Métodos: Para a coleta dos dados utilizou-se a pesquisa qualitativa através da estratégia de grupos focais realizados com pacientes em tratamento clínico (grupo 1) e pacientes submetidos à cirurgia antiglaucomatosa (grupo 2). A análise e a interpretação dos resultados foram feitas pela técnica da análise de conteúdo. Resultados: O medo da cegueira e a desinformação sobre a doença foram os aspectos negativos mais encontrados com relação a ser portador de glaucoma. O grupo cirúrgico preferiu a situação atual quando comparada à necessidade do uso de medicação. Verificou-se que tanto o glaucoma quanto o seu tratamento impactaram profundamente esses pacientes e que, embora a preocupação com a doença ainda persista, os pacientes operados demonstraram apresentar menos impacto no seu cotidiano. Foram determinantes para a aceitação da indicação da cirurgia a falta de controle da doença e a confiança no médico, sendo esta última considerada um fator primordial nos dois grupos pesquisados, o que aponta para sua importância, independente da decisão tomada pelo paciente na convivência com sua doença. Conclusão: Identificaram-se os aspectos negativos mais relevantes com relação ao glaucoma e ao seu tratamento. A confiança na correta indicação do tipo de tratamento, clínico ou cirúrgico, e uma relação sólida entre o paciente o médico são os fatores determinantes para uma maior tranquilidade dos pacientes em tratamento de glaucoma (clínico ou cirúrgico).

Descritores: Glaucoma de ângulo aberto/psicologia; Glaucoma de ângulo aberto/terapia; Glaucoma de ângulo aberto/cirurgia; Qualidade de vida

\footnotetext{
${ }^{1}$ Fundação Hilton Rocha, Belo Horizonte, MG, Brazil.

${ }^{2}$ Universidade Federal de Juiz de Fora, Juiz de Fora, MG, Brazil.

${ }^{3}$ Faculdade de Ciências Médicas e da Saúde de Juiz de Fora, Juiz de Fora, MG, Brazil.

${ }^{4}$ Santa Casa de Misericórdia de Juiz de Fora, Juiz de Fora, MG, Brazil.
}

The authors declare no conflicts of interest

Received for publication 04/03/2015 - Accepted for publication 29/03/2015 


\section{INTRODUCTION}

$\mathbf{T}$ The maintenance and/or improvement of the quality of life at a reasonable cost should be seen as the highest goal of the glaucoma treatment. ${ }^{1,2}$ The quality of life is closely related to: the stage of visual function damage of the patient; the psychological impact of the disease and its treatment; the doctor-patient relationship; the cost and side effects of the treatment; the independence to perform household and work tasks, such as driving and reading; the inconvenience of instilling eyedrops; and disbelief in its true usefulness and efficiency due to missinformation..$^{3-11}$

To achieve properly and efficiently the goal of the glaucoma treatment, patient education and counselling by the doctor are very important in the pursuit of establishing a therapeutic regimen capable of overcoming the following barriers: age, ethnicity, sex and social class. ${ }^{2,4}$ There are also other more subjective factors that may serve as barriers to the treatment proposed, such as: values, beliefs and culture of the patients. ${ }^{11,12}$

Basically the glaucoma treatment is accomplished through the proper control of intraocular pressure, which may be done with medication (eyedrops), laser or surgery. ${ }^{13}$ The guidelines for glaucoma treatment advise to always start the treatment with eyedrops, and classically surgery is left for cases where medical treatment is not well indicated (intolerance, cost, low adherence and persistence) or is not enough..$^{14,15}$

There is no evidence in the literature of what kind of glaucoma treatment is preferred by the patients. What is the impact of having glaucoma for the patient? What do they think about the treatment? How is the possible need for surgery understood and how it influences the treatment? These are some examples of questions that would be very difficult to be answered with a quantitative methodology. In the medical literature qualitative studies that attempt to clarify the beliefs and values assigned by glaucoma patients themselves to the type of treatment (medical or surgical) proposed by the doctor are virtually absent.

This study aimed to identify, from the perspective of patients, the meaning of being a glaucoma carrier, emphasizing the impact of this disease on their quality of life and in the perception (values, beliefs, fears) that had about the type of treatment (clinical versus surgical).

\section{Methods}

The method proposed for this study is based on the assumptions of qualitative research, where we work with the notions of meaning, beliefs, aspirations, reasons, values and attitudes, seeking an approch with the object of study, as proposed by Minayo. ${ }^{16}$

The field of study chosen was a private clinic specialized in glaucoma, and the research project was approved by the Research Ethics Committee of the Charity Hospital of Juiz de Fora (SCMJF) by Opinion No. 040/2011.

As methodological strategy for collecting data, this study used focus groups (discussions and presentation of ideas in group) and individual semi-structured interviews, when necessary, used to complement the data obtained during the group discussion.
The clinical data of the patients was obtained through the analysis of their medical records, and were used to characterize the research participants. The study groups were formed of patients in clinical treatment (group 1) and patients who had undergone the glaucoma surgery (group 2), and the criteria for inclusion in the study were: patients over 21 years old with controled and in advanced stage primary open-angle glaucoma (index Mean Deviation of computerized campimetry $<-12.00 \mathrm{~dB}$ ) in at least 1 eye. In group 1 patients were in continuous use of antiglaucoma eyedrops in both eyes, and in group 2 they underwent surgery in both eyes at least one year before. We excluded those patients who had been operated and that had returned to the chronic use of antiglaucoma eyedrops, as well as patients whose desease were not considered controlled by the attending physician (Table 1).

The selection of patients who meet the inclusion criteria was made through invitation to them when they went to their appointment consecutively until completing the number of 10 patients per group. All the patients read, agreed and signed the Informed Consent Term approved by the Research Ethics Committee of the SCMJF.

For the focal group, we used a script of questions previously elaborated based on guiding questions (Example: How do you deal with the fact of having glaucoma? What do you think about the treatment? How do you understand the need for surgery and how it influences the treatment?). The questions were pre-tested with patients with the same characteristics of the future survey subjects.

The meetings with the groups were in different days, and data collection was interrupted when the "saturation point" was reached, i.e., when information obtained during the group dynamics and the interviews became recurrent.

The discussions and interviews were recorded on electronic media, and later literally transcribed. The content obtained was organized and categorized along with the document research based on the operation summarized in Minayo $^{16}$, which consists of three steps: pre-analysis; study of the material; and treatment of the results obtained and interpretation.

The procedures for the data analysis were based on the content analysis technique. Finally, the data obtained was related to the theoretical framework adopted, in order to apprehend the subjects' perception on the core question of this study, i.e., the perception of subjects surveyed about glaucoma and its treatment.

\section{RESULTS}

From the 10 patients selected to bex each sample group, only 9 attended the meeting. The characteristics of each one of the participants are described in Table1, and the subjects in group 1 are coded by numbers ( 1 to 9 ) and in group 2 by letters ('A' through 'I').

The medical discourse and common sense contribute at the same time to the meaning of the "having glaucoma", unanimously translated by fear of blindness, mentioned several times by the subjects interviewed (Table 2). Some patients have reported lack of knowledge about glaucoma before being diagnosed with the disease. Speeches like "I got gcared for not 
Table 1

Características dos participantes da pesquisa:

\begin{tabular}{|c|c|c|c|c|c|c|}
\hline $\begin{array}{l}\text { Group 1: } \\
\text { Clinical } \\
\text { treatment }\end{array}$ & $\begin{array}{l}\text { Age } \\
\text { (years) }\end{array}$ & Ethnicity & Sex & Education & $\begin{array}{l}\text { Time since the discovery } \\
\text { of the disease (anos) }\end{array}$ & $\begin{array}{c}\text { Number of droplet } \\
\text { per day per eye }\end{array}$ \\
\hline Patient 1 & 75 & white & $\mathrm{M}$ & High school & 7 & 5 \\
\hline Patient 3 & 69 & black & $\mathrm{F}$ & Graduated & 10 & 1 \\
\hline Patient 4 & 65 & black & $\mathrm{F}$ & Elementary & 11 & 5 \\
\hline Patient 5 & 93 & white & $\mathrm{F}$ & Elementary & 2 & 6 \\
\hline Patient 7 & 63 & white & $\mathrm{F}$ & Elementary & 15 & 6 \\
\hline Patient 8 & 72 & white & M & Elementary & 1 & 3 \\
\hline Patient 9 & 83 & white & M & Graduated & 20 & 3 \\
\hline $\begin{array}{c}\text { Group 2: } \\
\text { Clinical } \\
\text { treatment }\end{array}$ & $\begin{array}{l}\text { Age } \\
\text { (years) }\end{array}$ & Ethnicity & Sex & Education & $\begin{array}{l}\text { Time since the discovery } \\
\text { of the disease (anos) }\end{array}$ & $\begin{array}{c}\text { Number of droplet } \\
\text { per day per eye }\end{array}$ \\
\hline Patient D & 55 & white & M & Graduated & 13 & 3 \\
\hline Patient E & 81 & white & $\mathrm{F}$ & High school & 6 & 2 \\
\hline Patient $\mathrm{F}$ & 47 & white & M & Elementary & 34 & 5 \\
\hline Patient $G$ & 70 & white & $\mathrm{F}$ & Graduated & 26 & 5 \\
\hline Patient $\mathrm{H}$ & 68 & white & $\mathrm{F}$ & High school & 30 & 4 \\
\hline Patient I & 58 & white & $\mathrm{F}$ & Elementary & 10 & 3 \\
\hline
\end{tabular}

knowing it" (Patient 1) and "I had never heard about this particular desease" (Patient 1) are examples of how lack of knowlege can generate an even greater negative impact in the diagnosis of glaucoma.

Patients mentioned that giving up activities that gave them pleasure or that were part of their routine was a difficult change to accept. Some examples are as follows: "I stopped working earlier than I wanted to. For example, driving. I've always wanted to get my license, but I never could (Patient 6); "When I knew I

Table 2

Examples of speeches about the subjet "having glaucoma".

\begin{tabular}{l|l}
\hline Patient 4 & $\begin{array}{l}\text { "At first, I was very worried about blindness. } \\
\text { I couldn't read." }\end{array}$ \\
\hline Patient 5 & $\begin{array}{l}\text { "Really worried about being blind. I was afraid } \\
\text { of falling; I was really concerned." }\end{array}$ \\
\hline Patient 8 & $\begin{array}{l}\text { "I heard glaucoma was blindness for sure. But } \\
\text { the doctor said it wasn't true at all." }\end{array}$ \\
\hline Patient 9 & $\begin{array}{l}\text { "I got, like, really worried. My mother was } \\
\text { blind before dying." }\end{array}$ \\
\hline
\end{tabular}

had glaucoma, I had to stop working, and now I don't work anymore, you know..." (Patient 7).

During the meetings of the focus groups, the speeches about the use of eyedrops were recurrent, even in patients who had undergone surgery and were no longer using them. The need for chronic use of eyedrops generated discussions related to the concern of relying on an expensive drug, as well as the discomfort represented by the change of routine due to the care involved in the correct use of eyedrops.

Patients in the clinical group were the ones who talked the most about the cost of the drug treatment. All patients in this group were unanimous when reporting the problems related to the chronic use of medication. Table 3 gives some examples of speeches about the patients' perception on the routine of the chronic treatment with eyedrops.

The pharmacological treatment then becomes a necessary discomfort, according to the speeches of all patients interviewed. In the clinical group, living with the eyedrops is considered a dependence of which they complain, claiming concern for forgetting or having difficulties in the transportation because of the need to keep some medicines under refrigeration. The concern with time was dominant, and some even affirmed they make use of the most diverse and creative resources, such as the use of warnings or "timers".

In the surgical group we noted a kind of freedom in relation to such routine. This group showed satisfaction with the freedom that surgery provided; however, they were still concerned about the disease and the possible need to use the medication again.

Table 4 shows examples of speeches about the patients' perception regarding the surgical treatment of glaucoma. Side effects were remembered by patients in the surgical group, such as: bitter taste, blurred vision after instillation, dry eye and allergy, confirmed by the patients in the clinical group, which still make chronic use of same. 
Table 3

Examples of speeches about the difficulties and concerns an the clinical treatment of glaucoma

\begin{tabular}{l|l}
\hline Patient 2 & $\begin{array}{l}\text { "Besides price, what I think is absurd is the } \\
\text { amount. The amount is minimal! If we miss } \\
\text { one drop, it is worth gold!" }\end{array}$ \\
\hline Patient 3 & $\begin{array}{l}\text { "In one month the situation got worse: three } \\
\text { people using eyedrops" (in the family). }\end{array}$ \\
\hline Patient 4 & $\begin{array}{l}\text { "But it's so expensive, so expensive that I } \\
\text { came came up with the decision of asking the } \\
\text { doctor if I could change the medicine" }\end{array}$ \\
\hline Patient 2 & $\begin{array}{l}\text { "I put my eyedrops in two shelves, in the } \\
\text { bathrooms... with a warning!" }\end{array}$ \\
\hline Patient 6 & $\begin{array}{l}\text { "To me, it's so bad to use eyedrops every ten } \\
\text { minutes. I need a timer... to track time." }\end{array}$ \\
\hline Patient 8 & $\begin{array}{l}\text { "In this sense, this thing of instilling eyedrops } \\
\text { at a certain time bothers me and makes me } \\
\text { very uncomfortable." }\end{array}$ \\
\hline
\end{tabular}

For patients in surgical treatment group, the main motivation for undergoing surgery was the medical indication, given the inability to control glaucoma only with topical medication. The fear of being blind, even though in treatment with eyedrops, made patients accept the surgical indication as a valid option.

\section{Discussion}

When trying to understand the meaning of "having glaucoma", other aspects should be considered besides the biological and physiological ones, and the treatment of the sick body. The glaucoma patient assimilates what society offers in terms of values, information, ideas, and theories, building from that their own history, becoming a socio-historical-cultural being. ${ }^{17,18}$

The visual assessment itself is often more valued (clinical data of ophthalmological examination) than the impact of vision loss, or even the threat that this loss may represent on these people lives, because "having glaucoma" is the same as no longer being productive, no longer being independent, is facing the unknown, a situation the patient fears. The lack of information about the disease and the fear of blindness were themes really mentioned by the patients in this study. "Having glaucoma" for some patients means certain blindness, and the lack if information generated anxiety and fear about the disease.

Education about the disease becomes important not only to the patient already diagnosed with the disease, but also to the general population. A more conscious society on glaucoma would help reduce the psychological impact of "having glaucoma".

The clinical treatment of glaucoma can paradoxically compromise the quality of life of the patient. Need for chronic use of medication, possible side effects, concerns and anxieties
Table 4 Examples of speeches about the patients' perception
regarding the surgical treatment:

\begin{tabular}{|c|c|}
\hline Patient A & $\begin{array}{l}\text { "...anyway I would choose surgery... eyedrops } \\
\text { are expensive and you'll be using and not } \\
\text { solving the problem of pressure."”... but the } \\
\text { doctor seems confident." }\end{array}$ \\
\hline Patient B & $\begin{array}{l}\text { "...I really prefer the surgery. And trust in } \\
\text { God first and then the doctor." }\end{array}$ \\
\hline Patient D & $\begin{array}{l}\text { "...surgery is the last stage.""So I think there } \\
\text { are many risks in it (Authors' note: regarding } \\
\text { the indication of treatment), especially the } \\
\text { trust relation between the patient and the } \\
\text { doctor. Many times the doctor is more } \\
\text { important than the medical or surgical } \\
\text { treatment." }\end{array}$ \\
\hline Patient E & $\begin{array}{l}\text { "...I feel better after the surgery because I } \\
\text { think I'm free from the evil...."”And when we } \\
\text { find a doctor who gives us attention, who speaks } \\
\text { clearly, objectively, we trust them and go on." }\end{array}$ \\
\hline Patient $\mathrm{F}$ & $\begin{array}{l}\text { "...I trust better the surgery. Surgery nipped } \\
\text { the evil in the bud." }\end{array}$ \\
\hline Patient $G$ & $\begin{array}{l}\text { “...my eye got very red when I instilled } \\
\text { eyedrops. I prefer surgery.","”..in my case } \\
\text { eyedrops were not working, so I had to go on } \\
\text { surgery. But always trusting, because I knew } \\
\text { God and the doctor were there for me." }\end{array}$ \\
\hline Patient $\mathrm{H}$ & $\begin{array}{l}\text { "The eyedrops were not working for me... I } \\
\text { was afraid of being blind."'We must trust the } \\
\text { doctor." }\end{array}$ \\
\hline Patient I & $\begin{array}{l}\text { "...I am allergic to drops. I can not use any } \\
\text { eyedrops! So I had to go on surgery, you } \\
\text { know..."”...I also prefer the surgery because I } \\
\text { really trust the doctor. First God, then her." }\end{array}$ \\
\hline
\end{tabular}

about the daily routine of treatment are some examples mentioned by patients in the presnet study about the negative impact on the quality of life of the patients chronicaly using eyedrops. Another important factor is the cost of the treatment. Speeches like type "each droplet is worth gold" were reccurent during the interviews. The need to sacrifice part of the family budget also has a big impact, since the patient gives up "extra" activities. Such activities which rely on part of their salary now spent on medication could represent an improvement of the same quality of life. In this context are includes trips, special meals, leisure, among others.

Glaucoma and its chronic course requires prolonged treatment and follow-up, and a high cost that can compromise $25 \%$ or more of the patient's family income. A Brazilian study found out that the lack of financial resources was reported by $47.6 \%$ of respondents as the main cause of treatment discontinuation, making the adhesion difficult and being responsible for the loss of visual field. ${ }^{8}$ The difficulties in using 
eyedrops are added to the cost itself, since each lost droplet has to be administered again.

Studies comparing the different kinds of glaucoma treatment using the quality of life as an outcome are rare. Encouraged by the clinical impression that the glaucoma-operated undergoing have a better quality of life than those in chronic use of eyedrops, researchers in the United States (Collaborative Initial Glaucoma Treatment Study - CIGTS), randomized newly diagnosed glaucoma patients for clinical or surgical treatment (Trabeculectomy). Both groups had worse quality of life indexes soon after the diagnosis. The indexes were improving during the follow-up (9 years), demonstrating that patients tend to get used to the disease and its treatment. Patients in the surgical group had a slight worsening of quality of life in the early postoperative stage, directly linked to the local effects of the surgery. In the long term, the quality of life indexes did not differ. ${ }^{19}$

In Brazil, Paletta Guedes et al. identified, also by means of a questionnaire, that patients with early-stage of glaucoma showed an association between surgical treatment and lower indexes of quality of life, which did not happen to more advanced stages of the disease. The most affected dimension in these cases was the psychological one, leading to the belief that a surgery for early glaucoma patients can give a great psychological impact. ${ }^{20}$

The question of patient preference on the type of treatment (medical or surgical) is difficult to be elucidated with quantitative research, as mentioned above. The CIGTS could not answer this question, and it can be seen in the research of Paletta Guedes et. al. ${ }^{20}$ that choosing the type of treatment may have a nonnegligible psychological impact for some patients.

Before surgery, the patients in this study who had undergone surgical treatment were chronic users of eyedrops for a long time, and now were free of this commitment. So they had a unique condition of having lived the problem both from a clinical treatment point of view and from the point of view of the surgical treatment. When asked about their preference between the two conditions (clinical treatment versus surgical treatment), they were unanimous in reporting that they preferred surgery, and despite the discomfort of using eyedrops, confidence in the medical indication and a good control of the disease were the most important factors for this treatment option.

Confidence in the indication of the type of treatment, clinical or surgical, and a solid relationship between doctor and patient are the most important findings of the present study. A similar result was found by Lemaitre et al. ${ }^{21}$ In a study carried out with glaucoma patients who required a filtering surgery, these authors found that both the disease and the surgical procedure are sources of anxiety. The relationship between doctor and patient and the confidence in the indication of the treatment appeared as key to decreasing the preoperative anxiety reported by the patients. ${ }^{21}$

A limitation of the present study is that the sample may not be representative of the entire population of primary openangle glaucoma patients. This fact is inherent in any survey conducted by the qualitative method because it is intended to deepen the most the question to be answered, and not generalize it. The saturation point for the qualitative methodology is an indication that a larger sample would be unnecessary to achieve the goal proposed in this research. A deep understanding of values, beliefs, concerns, anxieties and fears is only possible by means of a qualitative research.

Another limitation is that patients in the surgical group may have been influenced by the conduct of the attending physician (type of surgical technique). Also as a limitation we can mention the fact that the research was conducted in a private practice environment, which may influence the perception of the patients. We believe that values, beliefs and culture base are different between patients attending a private clinic and those who are seen at the Single Health System (SUS). Another similar study with patients enrolled in the Single Health System (SUS) could clarify this point. However, these limitations do not invalidate our results.

In conclusion, glaucoma gives patients a deep sense of fear and concern not about the loss of vision, but also about the impact of the disease and its treatment on their daily lives. The cost and side effects of the clinical treatment were the main negative factors raised by the patients. The patients in the surgical group were unanimous in preferring surgery in relation to the chronic use of eyedrops. Glaucoma-operated patients seem to have less negative impact on their daily lives, but the concern about the disease persists.

The confidence in the doctor and the correct indication of proper treatment, be it clinical or surgical, is a major factor for extra peace of mind of the patient. The ophthalmologist is privileged with regard to the possibility of contributing to the reduction of the patient's anxiety about the procedures necessary to a better quality of life.

\section{RefERENCES}

1. Dietlein TS, Hermann MM, Jordan JF. The medical and surgical treatment of glaucoma. Dtsch Arztebl Int. 2009; 106(37):597-606.

2. Silva LR, Paula JS, Rocha EM, Rodrigues ML. Fatores relacionados à fidelidade ao tratamento do glaucoma: opiniões de pacientes de um hospital universitário Arq Bras Oftalmol. 2010; 73(2):116-9.

3. Hong S, Kang SY, Yoon JU, Kang U, Seong GJ, Kim CY. Drug attitude and adherence to anti-glaucoma medication. Yonsei Med J. 2010; 51(2):261-9.

4. Kulkarni SV, Damji KF, Buys YM. Medical management of primary open-angle glaucoma: best practices associated with enhanced patient compliance and persistency. Patient Prefer Adherence. 2008; 2:313-4.

5. World Health Organization (WHO)/ International Agency for the Prevention of Blindness. Data Vision 2020: the right to sight. Global initiative for the elimination of avoidable blindness: action plan 2006-2011. Geneva: WHO International Agency for the Prevention of Blindness; 2007.

6. Mello PA, Melo Júnior LA. Glaucoma dos nossos dias: revendo conceitos e custos. Rev Bras Oftalmol. 2003; 62(9):669-77.

7. Ramulu P. Glaucoma and disability: which tasks are affected, and at what stage of disease? Curr Opin Ophthalmol. 2009; 20(2):92-8.

8. Silva LM, Vasconcellos JP, Temporini ER, Costa VP, NewtonCara J. Tratamento clínico do glaucoma em um hospital universitário: custo mensal e impacto na renda familiar. Arq Bras Oftalmol. 2002;65(2):299-303.

9. European Glaucoma Society (EGS). Terminology and guidelines for glaucoma. 3a ed. Savona: Dogma; 2008.

10. Severn P, Fraser S, Finch T, May C. Which quality of life score is best for glaucoma patients and why? BMC Ophthalmol. 2008;8:2.

11. Lacey J, Cate H, Brodway DC. Barriers to adherence with glaucoma medications: a qualitative research study. Eye (Lond). 2009; 23(4):924-32.

12. Almeida LD, Machado MC. Atitude médica e autonomia do doente vulnerável. Rev Bioética. 2010;18(1):165-83. 
13. Leske MC, Heijl A, Hyman L, Bengtsson B, Komaroff E. Factors for progression and glaucoma treatment: the early manifest glaucoma trial. Curr Opin Ophthalmol. 2004;15(2):102-6.

14. Nayak B, Gupta S, Kumar G, Dada T, Gupta V, Sihota R. Socioeconomics of long-term glaucoma therapy in India. Indian J Ophthalmol. 2015;63(1):20-4.

15. Heijl A, Leske MC, Bengtsson B, Hyman L, Bengtsson B, Hussein M; Early Manifest Glaucoma Trial Group. Reduction of intraocular pressure and glaucoma progression: results from the early manifest glaucoma trial. Arch Ophthalmol. 2002;120(10):1268-79.

16. Minayo MCS. O desafio do conhecimento: pesquisa qualitativa em saúde. 9a ed. São Paulo: Hucitec; 2006.

17. Cintra FA, Sawaia BB. A significação do glaucoma e a mediacão dos significados de velhice na perspectiva Vygotskiana: subsídios para a educação à saúde. Rev Esc Enferm USP. 2000; 34(4): 339-46.

18. Vigotsky LS. A formação social da mente. São Paulo: Martins Fontes; 1994.
19. Burr J, Azuara-Blanco A, Avenell A. Medical versus surgical interventions for open-angle glaucoma. Cochrane Database Syst Rev. 2007; (4):CD004399.

20. Paletta Guedes RA, Paletta Guedes VM, Freitas SM, Chaoubah A. Quality of life of medically versus surgically treated glaucoma patients. J Glaucoma. 2012; 22(5):369-73.

21. Lemaitre S, Blumen-Ohana E, Akesbi J, Lapalce O, Nordmann JP. Evaluation of preoperative anxiety in patients requiring glaucoma filtration surgery. J Fr Ophtalmol. 2014; (1):47-53.

\section{Corresponding author:}

Augusto Alves Pinho Vieira.

Rua Dr. Asclepíades da Paixão Lucas 147, Portal da Torre. 36037-462 Juiz de Fora MG.

Phone:(32) 3231 2111; (31) 88113691

E-mail: augustovieira.med@gmail.com 